\title{
Sequence analysis of OmNramp $\alpha$ and quantitative expression of Nramp homologues in different trout strains after infection with Myxobolus cerebralis
}

\author{
Ute Rucker, Mansour El-Matbouli*
}

Institute of Zoology, Fish Biology and Fish Diseases, University of Munich, Kaulbachstr. 37, 80539 Munich, Germany

\begin{abstract}
Salmonid whirling disease caused by the metazoan parasite Myxobolus cerebralis is an ongoing problem in wild and farmed rainbow trout Oncorhynchus mykiss populations. Rainbow trout from different strains vary in susceptibility to the parasite. Identification of underlying mechanisms could be a starting point for improved control of the disease. We conducted infection trials using 2 rainbow trout strains and brown trout Salmo trutta fario, a species not susceptible to the parasite, to investigate host immune response and resistance mechanisms. We compared expression levels of 2 natural resistance-associated macrophage proteins (Nramp $\alpha$ and $\beta$ ) after infection with $M$. cerebralis. Total RNA was extracted from skin, muscle, kidney, head and spinal column, and gene expression was quantified by real-time PCR. Significant decreases in expression of both genes were observed at different time points in the infected susceptible rainbow trout compared to the noninfected group. Furthermore, the OmNramp $\alpha$ (O. mykiss natural resistance-associated macrophage protein $\alpha$ ) sequences in 2 resistant and 1 non-resistant rainbow trout strain were analysed and compared for sequence aberrations.
\end{abstract}

KEY WORDS: Whirling disease $\cdot$ Myxobolus cerebralis $\cdot$ Nramp $\cdot$ Gene expression $\cdot$ Real-time PCR

\section{INTRODUCTION}

Whirling disease in salmonids, caused by the myxozoan parasite Myxobolus cerebralis, can presently be found in most countries that produce trout in aquaculture (Hedrick et al. 1998), and it has been responsible for severe ecological and economic damage to natural and farmed populations of salmonids. Rainbow trout Oncorhynchus mykiss has a much higher susceptibility to the disease than the original host brown trout Salmo trutta fario, which had a historic association with $M$. cerebralis in its original European range (Andree et al. 1999, Hedrick et al. 1999a). The fish-infective spore stage of the parasite, the triactinomyxon (TAM), attaches to the host gills and epidermis. After penetration of the epidermis, the parasite develops intracellularly and migrates through the subcutis and peripheral nervous tissue to the central nervous system, and then to nearby cartilage tissue (El-Matbouli et al. 1999, Hedrick \& El-Matbouli 2002). Subsequently, parasite development leads to destruction of the cartilage and gives rise to typical clinical signs: deformation of the head and spine, whirling swimming behaviour and a black tail (Schäperclaus 1990, Rose et al. 2000).

The immune and resistance mechanisms in the fish host against Myxobolus cerebralis are only poorly understood. Mucosal factors potentially affect TAM attachment, and the presence of eosinophilic granular leucocytes in root ganglia of infected brown trout strongly suggests a cellular protective response (Hedrick et al. 1999b). However, mechanisms for the differences in susceptibility between rainbow trout strains remain unknown.

In mammals, the ability of macrophages to kill phagocytosed pathogens is enhanced by the membrane protein Nramp 1. Bradley et al. (1974) observed expression of a single, dominant, autosomal gene $B c g / L s h / I t y$ on mouse chromosome 1 that could control growth of taxonomically and antigenically unrelated intracellular parasites including Salmonella typhim- 
urium, Leishmania donovani and Mycobacterium bovis. Vidal et al. (1993) isolated the gene and called it Nramp 1. Members of the Nramp family have since been isolated from humans (Kishi 1994), rats (Gunshin et al. 1997), birds (Hu et al. 1995), fish (Dorschner \& Phillips 1999), insects (Rodrigues et al. 1995), nematodes (The C. elegans Sequencing Consortium 1998), plants (Belouchi et al. 1995), yeast (Portnoy et al. 2000) and bacteria (Makui et al. 2000). The widespread occurrence of the gene suggests that Nramp protein functions may be essential for the survival of cells and organisms.

Structural analysis showed that vertebrate homologues share a 12 transmembrane domain topology, glycosylation, extensive phosphorylation, and a highly conserved binding protein-dependent transport system inner membrane component signature (Govoni et al. 1995). In mammals, Nramp 1 is preferentially expressed in phagocytic cells such as macrophages and polymorphnuclear leucocytes (Cellier et al. 1994, Govoni \& Gros 1998). A second mammalian gene Nramp 2 has been identified and, in contrast to Nramp 1, it is expressed at low levels in all tissues. Its protein has been identified as a pH-dependent divalent cation transporter and represents the major transferrin-independent iron uptake system of the mammalian intestine (Gunshin et al. 1997). Nramp genes code for integral membrane proteins that share $63 \%$ identical residues and an overall homology of $78 \%$. They share very similar secondary structure, including identical hydropathy profiles and predicted membrane organization, with a minimum of 10 and most probably 12 transmembrane domains, a cluster of predicted Nlinked glycosylation sites, and a consensus transport motif (Gruenheid et al. 1995).

Nramp 1 codes for an integral membrane protein which is localized to the late endocytic compartments of resting macrophages. Upon phagocytosis, Nramp 1 is recruited to the membrane of the phagosome and remains associated with this structure during its maturation to phagolysosome (Gruenheid et al. 1997). Gene knockout experiments in mice revealed that Nramp 1 plays an important role in the early stages of parasitemacrophage interactions (Govoni et al. 1996). Although the mechanism by which Nramp 1 confers innate resistance to intracellular pathogens remains unknown, there are several theories that attempt to explain its exact function. Jabado et al. (2000) used Nramp 1-expressing (+/+) and Nramp 1-deficient (-/-) macrophages to show that phagosomes from Nramp $1^{+/+}$macrophages extrude $\mathrm{Mn}^{2+}$ faster than their Nramp $1^{-/-}$counterparts. This difference is no longer visible when the acidification of the phagosomal lumen is dissipated, suggesting that $\mathrm{Mn}^{2+}$ transport of Nramp 1 is $p H$-dependent. The authors conclude that
Nramp 1, like Nramp 2, is a divalent cation transporter that may also transport other divalent cations like $\mathrm{Fe}^{2+}$ or $\mathrm{Zn}^{2+}$ out of the phagosomal lumen. These cations are presumed to be essential to metabolic activity of intracellular parasites. As Nramp homologues have also been identified in many bacterial species, it is possible that both macrophage and microbial homologues compete for metals in the microenvironment of the phagosome (Jabado et al. 2000).

There is also a wide range of other effects of Nramp 1 on macrophage activity, including regulation of interleukin- $\beta$ (IL- $\beta$ ), inducible nitric oxide (NO) synthase (iNOS), major histocompatibility complex (MHC) class II molecules, tumor necrosis factor alpha (TNF- $\alpha$ ), NO release, L-arginine flux, oxidative burst, and antigen presentation (Blackwell et al. 1994, Skamene 1994, Radzioch et al. 1995, Blackwell 1996, Lang et al. 1997).

The high degree of sequence and gene structure similarity within the Nramp family across species suggests that the protein cannot tolerate significant alteration in primary structure (Cellier et al. 1994, Blackwell et al. 1995, Govoni et al. 1995, Dorschner \& Phillips 1999). This was demonstrated by sequencing Nramp 1 cDNA clones in 27 inbred mouse strains; a single non-conservative Gly to Asp substitution in the murine Nramp 1 at position 169 causes susceptibility to Mycobacteria, Salmonella and Leishmania (Malo et al. 1994). This sequence aberrance appears in the 4 th transmembrane domain and may influence the integration of the protein into the phagosomal membrane (Malo et al. 1994). In humans, a linkage of polymorphisms in NRAMP 1 to susceptibility to tuberculosis is suspected (Hsu et al. 2006), but evidence is still weak. A polymorphism in the $3^{\prime}$ untranslated region of cattle Nramp 1 has an effect on expression of the gene and is also linked to Brucella abortus susceptibility (Barthel et al. 2001).

In rainbow trout, 2 Nramp proteins called OmNramp $\alpha$ and OmNramp $\beta$ (Oncorhynchus mykiss Nramp $\alpha$ and $\beta$ ) have been isolated. Detailed analysis showed that the evolutionary conservation of Nramp proteins extends to teleost fish, with a $69 \%$ identity to mammalian Nramp 1 homologues and a 78\% identity with Nramp 2 proteins (Dorschner \& Phillips 1999).

The current study was designed to investigate Nramp as a candidate gene for resistance of rainbow and brown trout to Myxobolus cerebralis. The expression of Nramp in non-infected and infected fish was estimated quantitatively. The second aim was to define polymorphisms in the rainbow trout Nramp homologue OmNramp $\alpha$ in rainbow trout strains with differing resistance and susceptibility to $M$. cerebralis. Although the OmNramp $\alpha$ sequence resembles that of the mammal Nramp 2, the trout version is preferentially expressed in the kidney and juvenile ovary, and with 
this tissue specific expression it shares an important characteristic of the mammal Nramp 1. For this reason we regard it as a candidate gene for resistance to disease.

\section{MATERIALS AND METHODS}

Primer design. For expression analysis, PCR primers were designed using the published rainbow trout OmNramp $\alpha$ and OmNramp $\beta$ sequences (Table 1). Positions of splice junctions were determined in order to facilitate positioning primers in a way that they overran at least one splice junction, to make sure they only amplified cDNA and not genomic DNA. The primers were analyzed for potential secondary structure and dimerization potential using Oligo software (Molecular Biology Insights) and were commercially synthesized

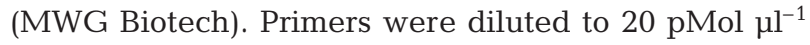
with $\mathrm{ddH}_{2} \mathrm{O}$ (double-distilled water) and used without further purification. In brown trout, Nramp $\alpha$ and $\beta$ homologues were detected with the specific primers OmNramp $\alpha$ F/R and OmNramp $\beta$ F/R. For this reason, the terms Nramp $\alpha$ and Nramp $\beta$ refer here to the target genes of both species (Oncorhynchus mykiss and Salmo trutta). Sequences and PCR conditions for rainbow trout $\beta$-actin primers were from Sigh et al. (2004). PCR detection of Myxobolus cerebralis was conducted according to Andree et al. (1998) (Tables 1 \& 2).

For sequence analysis of OmNramp $\alpha, 3$ primer pairs were constructed. Compl_ $\alpha$ F and Compl_ $\alpha$ R enclosed the whole open reading frame and were used for isolation of the gene. The primers pUCM_13 F and pUCM_13 R were specific for the cloning vector and were used for sequencing the 5' and 3' ends of the inserts. $691 \mathrm{~F}$ and $1348 \mathrm{R}$ were again specific for OmNramp $\alpha$ and were used for sequencing the inner part of the inserts.

Fish and rearing conditions. For real-time quantification, 2 rainbow trout strains and 1 brown trout strain were used in this study, i.e. a hatchery rainbow trout strain named TL from the USA that was highly susceptibility to Myxobolus cerebralis, a self-reproducing wild strain of rainbow trout from Germany (WT) which was resistant to the parasite, and brown trout Salmo trutta fario (BT) which is regarded as the highly resistant original host of $M$. cerebralis. For sequence analysis, one more German hatchery strain (HO) which has a high level of resistance was used. Specific-pathogenfree (SPF) fish were obtained as eggs and were hatched and reared in our wet laboratory at $15^{\circ} \mathrm{C}$. For the entire experiment, fish were fed commercial trout feed at $1 \%$ body weight $\mathrm{d}^{-1}$.

Parasites. The complete life cycle of Myxobolus cerebralis has been established in our laboratory. For exposure of the fish, fresh triactinomyxon spores were maintained by filtering (filter gauze, $20 \mu \mathrm{m}$ pore size) the water in tanks containing infected Tubifex tubifex worms.

Infection procedure. For infection experiments, $54 \mathrm{~d}$ old (810 degree-days post hatching) fish were used. From each strain, 15 fish were exposed to 75000 freshly filtered triactinomyxon spores (5000 spores fish $^{-1}$ ) for $1 \mathrm{~h}$ in $1 \mathrm{l}$ tanks without water flow. This is an

Table 1. Primers used for expression analysis

\begin{tabular}{|c|c|c|c|c|}
\hline Gene target & $\begin{array}{l}\text { Size of amplicon } \\
\text { (bp) }\end{array}$ & Designation & Sequence $\left(5^{\prime}-3^{\prime}\right)$ & $\begin{array}{l}\text { GenBank } \\
\text { accession no. }\end{array}$ \\
\hline \multicolumn{5}{|c|}{ Primers used for real-time PCR } \\
\hline$\beta$-actin & 260 & $\begin{array}{l}\text { Bact }-\mathrm{F} \\
\text { Bact }-\mathrm{R}\end{array}$ & $\begin{array}{l}\text { ATGGAAGGTGAAATCGCC } \\
\text { TGCCAGATCTTCTCCATG }\end{array}$ & AF157514 \\
\hline Nramp $\alpha$ & 230 & $\begin{array}{l}\text { OmNramp } \alpha F \\
\text { OmNramp } \alpha R\end{array}$ & $\begin{array}{l}\text { TTCTTCTCACCCGCTCCATCG } \\
\text { CACAGACCACCAGGATGACCA }\end{array}$ & AF048760 \\
\hline Nramp $\beta$ & 244 & $\begin{array}{l}\text { OmNramp } \beta \text { F } \\
\text { OmNramp } \beta \text { R }\end{array}$ & $\begin{array}{l}\text { GACTTTGCTAATGGACTGGTG } \\
\text { TTGTTGCTTACCCTGTTGCC }\end{array}$ & AF048761 \\
\hline \multicolumn{5}{|c|}{ Primers used for the detection of Myxobolus cerebralis } \\
\hline $\begin{array}{l}\text { 18S rDNA of } \\
\text { M. cerebralis }\end{array}$ & 415 & $\begin{array}{l}\operatorname{Tr} 5-17 \\
\operatorname{Tr} 3-17\end{array}$ & $\begin{array}{l}\text { GCCCTATTAACTAGTTGGTAGTATAGAAGC } \\
\text { GGCACACTACTCCAACACTGAATTTG }\end{array}$ & U96492 \\
\hline \multicolumn{5}{|c|}{ Primers used for OmNramp $\alpha$ sequencing } \\
\hline OmNramp $\alpha$ & 1852 & 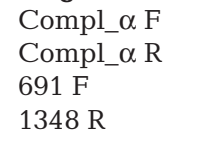 & $\begin{array}{l}\text { CTAATGAAGACAGCGCGGGA } \\
\text { ATGAGGATGGGCACTTACGA } \\
\text { CGCCAGGGTTTTCCCAGTCACGAC } \\
\text { TCACACAGGAAACAGCTATGAC }\end{array}$ & AF048760 \\
\hline \multicolumn{2}{|c|}{$\begin{array}{l}\text { Insert in } \mathrm{pGEM}^{\circledR} \text {-T } \\
\text { vector }\end{array}$} & $\begin{array}{l}\text { pUCM_13 F } \\
\text { PUCM_13 R }\end{array}$ & $\begin{array}{l}\text { CGCCAGGGTTTTCCCAGTCACGAC } \\
\text { TCACACAGGAAACAGCTATGAC }\end{array}$ & \\
\hline
\end{tabular}


Table 2. Cycle parameters for the polymerase chain reactions

\begin{tabular}{|c|c|c|c|c|c|}
\hline Target cDNA & Denaturation & Annealing & Elongation & Extension & No. of cycles \\
\hline \multicolumn{6}{|l|}{ Real-time PCR } \\
\hline \multirow[t]{2}{*}{$\beta$-actin } & $95^{\circ} \mathrm{C}$ for $3 \mathrm{~min}$ & - & - & - & 1 \\
\hline & $94^{\circ} \mathrm{C}$ for $45 \mathrm{~s}$ & $58^{\circ} \mathrm{C}$ for $45 \mathrm{~s}$ & $72^{\circ} \mathrm{C}$ for $45 \mathrm{~s}$ & & 35 \\
\hline \multirow[t]{2}{*}{ Nramp $\alpha$} & $95^{\circ} \mathrm{C}$ for $3 \mathrm{~min}$ & - & - & - & 1 \\
\hline & $95^{\circ} \mathrm{C}$ for $30 \mathrm{~s}$ & $68.5^{\circ} \mathrm{C}$ for $20 \mathrm{~s}$ & $72^{\circ} \mathrm{C}$ for $20 \mathrm{~s}$ & - & 40 \\
\hline \multirow[t]{2}{*}{ Nramp $\beta$} & $95^{\circ} \mathrm{C}$ for $3 \mathrm{~min}$ & - & - & - & 1 \\
\hline & $95^{\circ} \mathrm{C}$ for $30 \mathrm{~s}$ & $64.6^{\circ} \mathrm{C}$ for $20 \mathrm{~s}$ & $72^{\circ} \mathrm{C}$ for $20 \mathrm{~s}$ & - & 40 \\
\hline \multicolumn{6}{|l|}{ Conventional PCR } \\
\hline 18S rDNA of & $95^{\circ} \mathrm{C}$ for $5 \mathrm{~min}$ & - & - & - & 1 \\
\hline \multirow[t]{2}{*}{ Myxobolus cerebralis } & $95^{\circ} \mathrm{C}$ for $1 \mathrm{~min}$ & $65^{\circ} \mathrm{C}$ for $2.5 \mathrm{~min}$ & $72^{\circ} \mathrm{C}$ for $1.5 \mathrm{~min}$ & - & 35 \\
\hline & - & - & - & $72^{\circ} \mathrm{C}$ for $10 \mathrm{~min}$ & 1 \\
\hline
\end{tabular}

infection dose comparable to natural infection, where the spore concentrations are lower but the fish are exposed to the TAM spores over a longer period.

After $30 \mathrm{~min}$, water and oxygen (air) flow were supplied to the tanks. After $1 \mathrm{~h}$, the fish were transferred to $50 \mathrm{l}$ tanks with water flow at $15^{\circ} \mathrm{C}$. Another 15 fish from each strain were treated in the same way, without exposure to triactinomyxon spores, and served as controls.

Tissue sampling and RNA isolation. At $3 \mathrm{~h}, 14 \mathrm{~d}$ and $40 \mathrm{~d}$ after exposure, 5 fish from each exposed and control group were sampled for expression analysis and detection of Myxobolus cerebralis infection. For tissue sampling, 2 incisions were made; one was cut vertically through the head cartilage behind the eye, followed by a horizontal incision along the lateral line to the anus. By doing this, we separated the upper half of the body of each fish containing head and spinal column cartilage, skin, muscle, dorsal, anal and tail fin and kidney. These tissue samples were stored at $-80^{\circ} \mathrm{C}$ in RNAlater ${ }^{\circledR}$ (Sigma-Aldrich). For purification, the tissue samples were immersed in liquid nitrogen and ground with a mortar and pestle. Thirty mg of the tissue powder was used for extraction of total RNA with RNeasy Mini Kit (Qiagen) according to the manufacturer's instructions. The RNA samples were DNasetreated using DNase I (Qiagen). The purity and quantity of the resulting RNA was determined spectrophotometrically by measuring the optical density at 260/280 nm. From total RNA, 1 ug was reverse transcribed using the iSCRIPT $^{\circledR}$ Kit (Bio-Rad). The resulting cDNA was divided in aliquots of $1 \mu \mathrm{l}$, replenished to a final amount of $10 \mu \mathrm{l}$, and stored at $-20^{\circ} \mathrm{C}$ prior to qualitative and quantitative PCR analysis.

Verification of the infection. Samples from all exposed fish were measured for infection with Мyхоbolus cerebralis using the single-round PCR of Andree et al. (1998) (Tables 1 \& 2) using the cDNA produced.
Amplification products were separated through 1.5\% agarose Tris-acetate EDTA (TAE) gels containing $10 \mu \mathrm{l}$ $\mathrm{ml}^{-1}$ ethidium bromide and photographed under UV illumination. cDNA from TAM spores served as positive control. A reaction mix with $\mathrm{ddH}_{2} \mathrm{O}$ instead of cDNA was used as a negative control.

Standard DNA plasmids construction. To obtain standard DNA for generating a standard curve for each target gene ( $\beta$-actin, Nramp $\alpha$, Nramp $\beta$ ), cDNA was amplified by PCR with the specific primer pairs (Table 1). PCR was carried out in a final reaction volume of $50 \mu$ l containing $46 \mu \mathrm{l} 1.1 \times$ ReddyMix PCR Master Mix (Abgene) comprising $75 \mathrm{mM}$ Tris- $\mathrm{HCl}(\mathrm{pH}$ 8.8), $20 \mathrm{mM}\left(\mathrm{NH}_{4}\right)_{2} \mathrm{SO}_{4}, 1.5 \mathrm{mM} \mathrm{MgCl}, 0.01 \%$ (v/v) Tween20, $0.2 \mathrm{mM}$ each of dATP, dCTP, dGTP, dTTP, 1.25 U Taq DNA polymerase, red dye for electrophoresis and $4 \mu \mathrm{l}$ of template cDNA with forward and reverse primers. PCR products were checked by agarose gel electrophoresis and directly ligated into the plasmid vector pGEM $^{\circledR}-\mathrm{T}$ (Promega). Escherichia coli JM109 High Efficiency Competent Cells (Promega) were then transformed with the ligation reaction according to the instructions of the manufacturer. Positive clones were checked for correct-sized inserts by PCR. Plasmid DNA was subsequently isolated following propagation of selected colonies using a GenElute Plasmid Miniprep Kit (Sigma-Aldrich). The inserts were released by a digest with Sca I (BioLabs) and purified using MinElute Gel Extraction Kit (Qiagen).

Quantification of cDNA by real-time PCR. The amplification of cDNA was measured by quantitative real-time PCR using an iCycler instrument (Bio-Rad). Fluorescence was detected by labelling the probes with SYBR Green I fluorophore. To generate a standard curve, a serial dilution of the released inserts was prepared by pipetting a 10-fold dilution series from $10^{2}$ to $10^{9}$. Real-time PCR was performed in 96well PCR plates in a final volume of $25 \mu$ l containing 
$10 \mu \mathrm{l}$ of attenuated inserts or diluted cDNA sample, $12.5 \mu \mathrm{iQ}{ }^{\mathrm{TM}}$ SYBR Green Supermix (Bio-Rad), and $1.25 \mu \mathrm{l}$ of each primer. PCR conditions for each primer pair can be seen on Table 2. Melting curves were obtained by performing a denaturation at $95^{\circ} \mathrm{C}$, followed by rehybridisation at $55^{\circ} \mathrm{C}$ and by progressive denaturation, raising the temperature to $95^{\circ} \mathrm{C}$ at a transition rate of $0.5^{\circ} \mathrm{C} \mathrm{s}^{-1}$ with continuous fluorescence measurement. Rainbow trout $\beta$-actin primers were used to normalize the starting quantity of cDNA using the calculation method of Vandesompele et al. (2002). Reaction mixes with $\mathrm{ddH}_{2} \mathrm{O}$ instead of diluted cDNA served as negative control. The significance in expression levels in infected fish was tested against the expression levels of uninfected controls using a Mann-Whitney $U$-test.

Sequence analysis. cDNA was taken from the kidney of fish from the strains HO, TL, and WT. A $1852 \mathrm{bp}$ fragment from nucleotide positions 20 to 1871 enclosing the whole open reading frame was amplified by PCR using the primers Compl_ $\alpha$ F and R. The PCR was carried out using $2 \times$ ReddyMix PCR Master Mix (Abgene) on an Eppendorf Thermal cycler with a cycling profile comprised of an initial denaturing step of $5 \mathrm{~min}$ at $94^{\circ} \mathrm{C}$, followed by 35 cycles of $94^{\circ} \mathrm{C}$ for $50 \mathrm{~s}, 56^{\circ} \mathrm{C}$ for $50 \mathrm{~s}$ and $72^{\circ} \mathrm{C}$ for $1.5 \mathrm{~min}$, and a final extension at $72^{\circ} \mathrm{C}$ for $7 \mathrm{~min}$. The PCR products were electrophoresed on $1 \%$ agarose gels and detected by ethidium bromide. One PCR product from each strain was purified using the PCR purification kit (Qiagen) according to the manufacturer's protocol, cloned into pGEM-T vector (Promega), and plasmids of 3 clones from each PCR product were purified using the Miniprep kit (Eppendorf). The 2 plasmidspecific primers pUCM_13 F and pUCM_13 R were used for the sequencing of the $5^{\prime}$ and $3^{\prime}$ ends of the inserts. The 2 additional gene-specific primers $961 \mathrm{R}$ and $1348 \mathrm{~F}$ served for sequencing of the inner part. All the sequencing procedures were conducted by GATC Biotech.

Sequence variabilities and similarities between the sequences were determined according to Corpet (1988) and Hall (1999) using the MULTALIN and BIOEDIT 5.0.9 software (Table 3). The OmNramp $\alpha$

Table 3. Similarities of the OmNramp $\alpha$ sequences. HO: German hatchery strain of brown trout with elevated resistance to Myxobolus cerebralis; TL: hatchery rainbow trout strain highly susceptible to $M$. cerebralis; WT: rainbow trout resistant to $M$. cerebralis

\begin{tabular}{|lccc|}
\hline & HO & TL & WT \\
\hline GenBank (acc. no. AF048760) & 0.996 & 0.912 & 0.995 \\
HO & 1.000 & 0.913 & 0.997 \\
TL & - & 1.000 & 0.913 \\
\hline
\end{tabular}

sequence from GenBank was included in the analysis. Position numbers refer to this sequence.

\section{RESULTS}

Verification of Myxobolus cerebralis infection. As clinical signs are not apparent until 3 mo after an infection with $M$. cerebralis, the fish appeared healthy throughout the whole study. A $415 \mathrm{bp}$ band was present in $M$. cerebralis assay PCR in all samples of exposed fish, confirming successful infection.

Real-time PCR results. Evaluation of real-time PCR results showed a variable constitutive expression of both genes in all tissue samples (Fig. 1). In general, there was no significant difference in gene induction between infected and control groups at $3 \mathrm{~h}$. A significant depression in gene expression relative to uninfected controls was seen in the TL strain for Nramp $\alpha$ at $14 \mathrm{~d}$ and for Nramp $\beta$ at $40 \mathrm{~d}$. At no time was there a significant increase of target gene expression in any infected group compared to the non-infected controls.

Sequence analysis. On bp position 712 , a $\mathrm{C}$ in the $\mathrm{HO}$ and WT strains is replaced by a $\mathrm{G}$ in the GenBank sequence and TL strain. Other variable positions are at 1711 and 1822, where the bases A and G alternate throughout the strains. An interesting finding was a deletion in one clone of the strain TL, which enfolds $154 \mathrm{bp}$ and extends from position 1442 to 1595 . To calculate the similarity of the sequences of the strains and the GenBank sequence among each other, the clones have been recomposed to full length genes (Table 3).

\section{DISCUSSION}

Little is known about how interactions between the fish host and Myxobolus cerebralis lead to an increased resistance to the parasite infection, and how immune responses differ between resistant and susceptible individuals. The long association of brown trout with $M$. cerebralis is believed to be the reason for its enhanced resistance. This could be also the case for the wild rainbow trout strain used in this study, as these fish may represent a remnant population of the earliest rainbow trout introduced to Germany. However, some native American species such as coho salmon also show a strong resistance to the parasite (Hedrick et al. 1999b). This indicates an accidentally or selectively developed innate immunity that plays a proportionally greater role in resistance in fish than in homeothermic vertebrates (Jones 2001). While mucosal factors are likely to affect successful infection by triactinomyxon spores, recent studies also show the involvement (in blood and tissue) of the innate immune system (authors' unpubl. data). 


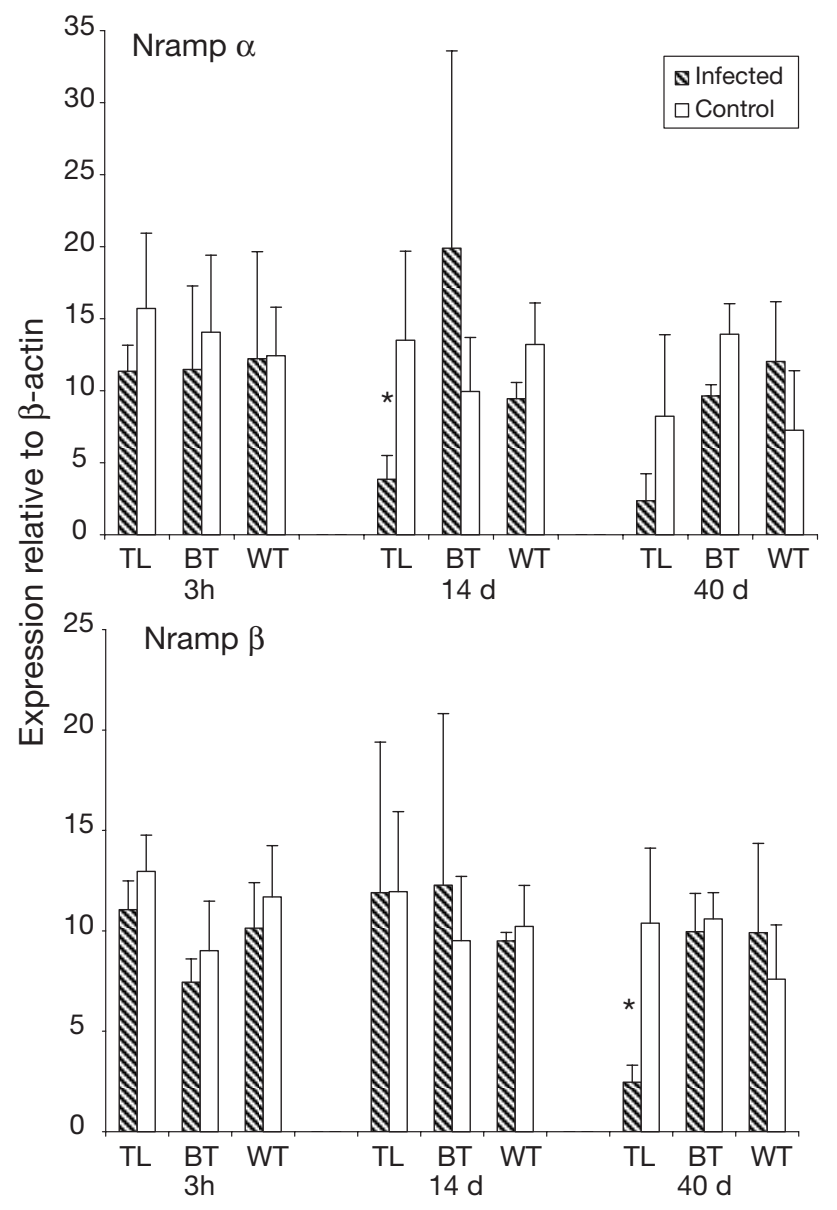

Fig. 1. Oncorhynchus mykiss (TL and WT strain) and Salmo trutta fario (BT). Real-time PCR amplification of target gene expression in tissue samples containing skin, muscle, head and spinal column bone and kidney. The expression of the specific genes is relative to $\beta$-actin expression levels. Bars represent mean $( \pm \mathrm{SD})$ expression level of 5 individual samples (infected and uninfected) except the WT strain at $14 \mathrm{~d}$ (4 samples for infected and uninfected group each) and WT strain at 40 d (3 samples for infected and uninfected group each). ${ }^{*}$ Significantly depressed expression (Mann-Whitney $U$-test, $\mathrm{p}<0.05)$; TL: hatchery rainbow trout strain highly susceptible to Myxobolus cerebralis; BT: brown trout highly resistant to parasite; WT: rainbow trout resistant to parasite

Nramp has been identified as an important part of the innate immune system that broadly stimulates macrophage activity and enhances macrophages' ability to kill phagocytised pathogens. This study was designed to investigate the role of Nramp in the increased resistance of a wild rainbow trout strain and brown trout to infection by Myxobolus cerebralis. We observed reduced expression of the 2 genes in the susceptible TL strain at $14 \mathrm{~d}(\mathrm{Nramp} \alpha)$ and $40 \mathrm{~d}$ (Nramp $\beta)$ post exposure. A similar expression pattern of Nramp 1 was recently reported by Sadeyen et al. (2004) in susceptible chickens after infection with Sal- monella. This finding may indicate a possible negative feedback mechanism involving Nramp (Baker et al. 2000). Similar reduced expression of genes following pathogen exposure has been observed in rainbow trout by other authors; however, the cause of the reduced expression is unknown (Grayson et al. 2002, Sigh et al. 2004, Overturf \& LaPatras 2006).

In several parasitic diseases, advanced pathology leads to a suppression of innate immune responses and enhances susceptibility to other diseases. This is mediated by the subsequent release of immune suppressive glucocorticoides (Elenkov \& Chrousos 1999). Holland et al. (2003) found that LPS-induced gene expression of several innate immune factors including COX-2, TNF- $\alpha 1$, IL-1 $\beta 1$, IL-1 $\beta 2$ and IL- 8 is suppressed in vitro by cortisol. Investigations on glococorticoide-mediated suppression of Nramp are not available, but as Nramp is involved in the regulation of some of the immune factors mentioned above, a coherence is possible.

The absence of any up-regulation of the 2 genes in infected fish suggests these genes are not influenced by Myxobolus cerebralis infection. We also investigated the possibility that a sequence aberration in an Nramp gene, expressed at normal level, is responsible for an enhanced susceptibility to the disease in fish possessing the aberrant sequence; studies on mammals have shown clear correlations between mutations and susceptibility to parasites (Malo et al. 1994). However, none of the sequence variabilities that have been detected here were specific to one strain; they were all found to be individual variations. The deletion that was found in one TL clone affects the whole 11th transmembrane domain and a part of the 12th transmembrane domain, and probably has a wide influence on the functionality of the protein. The other clones of the same fish did not have this deletion. We postulate that this deletion occurs in the other strains too, but has not been observed due to the limited number of clones that have been sequenced. Further studies are necessary to clarify the impact and/or function of this variability.

Acknowledgements. This work was supported by the Whirling Disease Foundation and the US Fish and Wildlife Service. We also thank E. Eszterbauer and H. Soliman for their assistance with the molecular work.

\section{LITERATURE CITED}

Andree KB, MacConnell E, Hedrick RP (1998) A nested polymerase chain reaction for the detection of genomic DNA of Myxobolus cerebralis in rainbow trout Oncorhynchus mykiss. Dis Aquat Org 34:145-154

Andree KB, El-Matbouli M, Hoffmann RW, Hedrick RP (1999) Comparison of $18 \mathrm{~S}$ and ITS-1 rDNA sequences of selected geographic isolates of Myxobolus cerebralis. Int J Parasitol 29:771-775 
Baker ST, Barton TE, Biggs TE (2000) A negative autoregulatory link between Nramp 1 function and expression. J Leukoc Biol 67:501-507

Barthel R, Feng J, Piedrahita JA, McMurray DN, Templeton JW, Adams LG (2001) Stable transfection of the bovine NRAMP1 gene into murine RAW264.7 cells: effect on Brucella abortus survival. Infect Immunol 69(5): 3110-3119

Belouchi A, Cellier M, Kwan T, Saini HS, Leroux G, Gros P (1995) The macrophage-specific membrane protein Nramp controlling natural resistance to infections in mice has homologues expressed in the root system of plants. Plant Mol Biol 29(6):1181-1196

Blackwell JM (1996) Structure and function of the naturalresistance associated macrophage protein (Nramp1), a candidate protein for infectious and autoimmune disease susceptibility. Mol Med Today 2:205-211

Blackwell JM, Barton $\mathrm{CH}$, White JK, Roach TI and 6 others (1994) Genetic regulation of leishmanial and mycobacterial infections: the Lsh/Ity/Bcg gene story continues. Immunol Lett 43(1-2):99-107

Blackwell JM, Barton CH, White JK, Searle S, Baker AM, Williams H, Shaw MA (1995) Genomic organization and sequence of the human NRAMP gene: identification and mapping of a promoter region polymorphism. Mol Med 1(2):194-205

Bradley DJ (1974) Genetic control of natural resistance to Leishmania donovani. Nature 250:353-354

C. elegans Sequencing Consortium (1995) Genome sequence of the nematode $C$. elegans: a platform for investigating biology. Science 282(5396):2012-2018

Cellier M, Govoni G, Vidal S, Kwan T and 6 others (1994) Human natural resistance-associated macrophage protein: cDNA cloning, chromosomal mapping, genomic organization, and tissue-specific expression. J Exp Med 180(5):1741-1752

Corpet F (1988) Multiple sequence alignment with hierarchical clustering. Nucl Acids Res 16(22):10881-10890

Dorschner MO, Phillips RB (1999) Comparative analysis of two Nramp loci from rainbow trout. DNA Cell Biol 18(7):573-583

Elenkov IJ, Chrousos GP (1999) Stress hormones, Th1Th2 patterns, pro/anti-inflammatory cytokines and susceptibility to disease. Trends Endocrinol Metab 9:359-368

El-Matbouli M, Hoffmann RW, Schoel H, McDowell TS, Hedrick RP (1999) Whirling disease: host specificity and interaction between the actinosporean stage of Myxobolus cerebralis and rainbow trout Oncorhynchus mykiss. Dis Aquat Org 35:1-12

Govoni G, Gros P (1998) Macrophage NRAMP1 and its role in resistance to microbial infections. Inflamm Res 47(7): $277-284$

Govoni G, Vidal S, Cellier M, Lepage P, Malo D, Gros P (1995) Genomic structure, promoter sequence, and induction of expression of the mouse Nramp 1 gene in macrophages. Genomics 27(1):9-19

Govoni G, Vidal S, Gauthier S, Skamene E, Malo D, Gros P (1996) The Bcg/Ity/Lsh locus: genetic transfer of resistance to infections in C57BL/6J mice transgenic for the Nramp 1 Gly169 allele. Infect Immunol 64(8):2923-2929

Grayson TH, Cooper LF, Wrathmell AB, Roper J, Evenden AJ, Gilpin ML (2002) Host responses to Renibacterium salmoninarum and specific components of the pathogen reveal the mechanisms of immune suppression and activation. Immunology 106:273-283

Gruenheid S, Cellier M, Vidal S, Gros P (1995) Identification and characterization of a second mouse Nramp gene. Genomics 25(2):514-525
Gruenheid S, Pinner E, Desjardins M, Gros P (1997) Natural resistance to infection with intracellular pathogens: the Nramp1 protein is recruited to the membrane of the phagosome. J Exp Med 85(4):717-730

Gunshin H, MacKenzie B, Berger UV, Gunshin Y and 5 others (1997) Cloning and characterization of a mammalian proton-coupled metal-ion transporter. Nature 388:482-488

Hall TA (1999) BioEdit: a user-friendly biological sequence alignment editor and analysis program for Windows 95/98/NT. Nucl Acids Symp Ser 41:95-98

Hedrick RP, El-Matbouli M (2002) Recent advances with taxonomy, life cycle, and development of Myxobolus cerebralis in the fish and oligochaete hosts. Am Fish Soc Symp 29:45-53

Hedrick RP, El-Matbouli M, Adkinson MA, McConnell E (1998) Whirling disease: re-emergence among wild trout. Immunol Rev 166:365-376

Hedrick RP, McDowell TS, Gay M, Marty GD, Georgiadis MP, McConnell E (1999a) Comparative susceptibility of rainbow trout Oncorhynchus mykiss and brown trout Salmo trutta to Myxobolus cerebralis, the cause of salmonid whirling disease. Dis Aquat Org 37:173-183

Hedrick RP, McDowell TS, Mukkatira K, Georgiadis MP, MacConnell E (1999b) Susceptibility of selected inland salmonids to experimentally induced infections with Myxobolus cerebralis, the causative agent of whirling disease. J Aquat Anim Health 11:330-339

Holland JW, Gould CRW, Jones CS, Noble LR, Secombes CJ (2003) The expression of immune-regulatory genes in rainbow trout, Oncorhynchus mykiss, during a natural outbreak of proliferative kidney disease (PKD). Parasitology 126:95-102

Hsu YH, Chen CW, Sun HS, Jou R, Lee JJ, Su IJ (2006) Association of NRAMP 1 gene polymorphism with susceptibility to tuberculosis in Taiwanese aboriginals. J Formos Med Assoc 105(5):363-369

Hu J, Bumstead N, Burke D, Ponce de Leon FA, Skamene E, Gros P, Malo D (1995) Genetic and physical mapping of the natural resistance-associated macrophage protein 1 (NRAMP1) in chicken. Mamm Genome 6(11):809-815

Jabado N, Jankowski A, Dougaparsad S, Picard V, Grinstein S, Gros P (2000) Natural resistance to intracellular infections: natural resistance-associated macrophage protein 1 (Nramp1) functions as a pH-dependent manganese transporter at the phagosomal membrane. Exp Med 192(9): $1237-1248$

Jones SRM (2001) The occurrence and mechanisms of innate immunity against parasites in fish. Dev Comp Immunol 25(8-9):841-852

Kishi F (1994) Isolation and characterization of human Nramp cDNA. Biochem Biophys Res Comm 204:1074-1080

Lang T, Prina E, Sibthorpe D, Blackwell J (1997) Nramp1 transfection transfers Ity/Lsh/Bcg-related pleiotropic effects on macrophage activation: influence on antigen processing and presentation. Infect Immunol 65:380-386

Makui H, Roig E, Cole ST, Helmann JD, Gros P, Cellier MF (2000) Identification of the Escherichia coli K-12 Nramp orthologue (MntH) as a selective divalent metal ion transporter. Mol Microbiol 35(5):1065-1078

Malo D, Vogan K, Vidal S, Hu J and 6 others (1994) Haplotype mapping and sequence analysis of the mouse Nramp gene predict susceptibility to infection with intracellular parasites. Genomics 23(1):51-61

Overturf K, LaPatra S (2006) Quantitative expression of immunological factors in rainbow trout, Oncorhynchus mykiss (Walbaum), after infection with either Flavobacterium psychrophilum, Aeromonas salmonicida, or infectious haematopoietic necrosis virus. J Fish Dis 29:215-224 
Portnoy ME, Liu XF, Culotta VC (2000) Saccharomyces cerevisiae expresses three functionally distinct homologues of the Nramp family of metal transporters. Mol Cell Biol 20(21):7893-7902

Radzioch D, Kramnik I, Skamene E (1995) Molecular mechanisms of natural resistance to mycobacterial infections. Circ Shock 44:115-120

Rodrigues V, Cheah PY, Ray K, Chia W (1995) Malvolio, the Drosophila homologue of mouse NRAMP-1 (Bcg), is expressed in macrophages and in the nervous system and is required for normal taste behaviour. EMBO J 14(13): 3007-3020

Rose JD, Marrs GS, Lewis C, Schisler G (2000) Whirling disease behaviour and its relation to pathology of brain stem and spinal cord in rainbow trout. J Aquat Anim Health 12: 107-118

Sadeyen JR, Trotereau J, Velge P, Marly J, Beaumont C, Barrow PA, Bumstead N, Lalmanach AC (2004) Salmonella

Editorial responsibility: Dieter Steinhagen,

Hannover, Germany carrier state in chicken: comparison of expression of immune response genes between susceptible and resistant animals. Microb Infect 6:1278-1286

Schäperclaus W (1990) Fischkrankheiten, 5th edn. AkademieVerlag, Berlin

Sigh J, Lindenstrom T, Buchmann K (2004) Expression of proinflammatory cytokines in rainbow trout (Oncorhynchus mykiss) during an infection with Ichthyophthirius multifiliis. Fish Shellfish Immunol 17(1):75-86

Skamene E (1994) The Bcg gene story. Immunobiology 191: 451-460

Vandesompele J, De Preter K, Pattyn F, Poppe B, Van Roy N, De Paepe A, Speleman F (2002) Accurate normalization of realtime quantitative RT-PCR data by geometric averaging of multiple internal control genes. Genome Biol 18:3-7

Vidal S, Malo D, Vogan K, Skamene E, Gros P (1993) Natural resistance to infection with intracellular parasites: isolation of a candidate gene for Bcg. Cell 73:469-475

Submitted: February 2, 2007; Accepted: May 24, 2007

Proofs received from author(s): July 10, 2007 